\title{
ARHGAP45 NP_036424.2:p.R139H
}

National Cancer Institute

\section{Source}

National Cancer Institute. ARHGAP45 NP 036424.2:P.R139H. NCI Thesaurus. Code C157550.

A change in the amino acid residue at position 139 in Rho GT Pase-activating protein 45 where arginine has been replaced by histidine. 